\title{
Investigation of measles outbreak-Herena and Dawe-Serer Districts of Bale Zone, Oromia Region, Ethiopia, February 2011
}

\author{
Abyot Bekele Woyessa*, Tesfaye Deti, Amanuel Yadata, Ashenafi Kenna, K Addisalem, M Yesuf, M Abebe \\ From 17th International Symposium on HIV and Emerging Infectious Diseases (ISHEID) \\ Marseille, France. 23-25 May 2012
}

\section{Introduction}

An estimated 10 million cases and 164,000 deaths from measles occur worldwide each year. On 08 Feb 2011 Bale Zonal health department reported suspected measles outbreak. We investigated to identify the etiology of the outbreak and undertake appropriate prevention and control interventions.

\section{Materials and methods}

Patient observation was made and active-cases were searched house to house. Medical registration-books were assessed and suspected measles cases were identified from 24-Nov-2010 to 15-Feb-2011 in Herena and Dawe-Serar districts using the following case definitions: maculopapular rash with fever $\geq 38.5^{\circ} \mathrm{C}$ with coryza, conjunctivitis or cough or epidemiologically linked by contact with laboratory confirmed outbreaks in neighboring districts. Immunization coverage and vaccine-storage facilities were assessed. Descriptive analysis was conducted using Epi-Info version3.5.1.

\section{Results}

A total of 329 suspected measles cases and 30 community deaths (case fatality rate (CFR) 9.1\%) were reported of which 159 (48.3\%) were from Dawe-Serar and 170 (51.7\%) were from Herena. CFR was 25/159 (15.7 \%) in Dawe-Serar and 5/170 (2.9\%) in Herena and higher among females than males (12.2\% vs. $6.1 \%)$. All deaths and $140 / 329(42.6 \%)$ of the cases were not vaccinated against measles. Vaccination coverage was $45.4 \%$ in Dawe-Serer and $54 \%$ in Herena. The attack rate was highest among those 15 years of age. About $5 / 7$ (71\%)

\footnotetext{
* Correspondence: sifanbashu@yahoo.com
Ethiopian Health and Nutrition Research Institute, Ethiopia, Addis Ababa,

* Correspondence: sifanbashu@yahoo.com
Ethiopian Health and Nutrition Research Institute, Ethiopia, Addis Ababa, Ethiopia
}

(c) 2012 Woyessa et al; licensee BioMed Central Ltd. This is an Open Access article distributed under the terms of the Creative Commons Attribution License (http://creativecommons.org/licenses/by/2.0), which permits unrestricted use, distribution, and reproduction in any medium, provided the original work is properly cited.

\section{and take full advantage of:}

- Convenient online submission

- Thorough peer review

- No space constraints or color figure charges

- Immediate publication on acceptance

- Inclusion in PubMed, CAS, Scopus and Google Scholar

- Research which is freely available for redistribution

Submit your manuscript at

C Biomed Central 